\title{
Organizing for Immigrant Rights: Policy Barriers and Community Campaigns
}

(revised version MS 818.08)

\author{
Jill Hanley, School of Social Work, McGill University \\ Eric Shragge, School of Community and Public Affairs, Concordia University
}

\begin{abstract}
Immigration to Canada has changed in basic ways the composition of the labor force. Over the past 40 years, a large wave of immigrants has arrived from the countries of the 'Global South'. Many have arrived with high levels of education and qualifications; however. The jobs they receive are at the bottom of the labor market. The Immigrant Workers Center (IWC) in Montreal is an organization that provides individual services, education on rights, and organizes immigrant workers for workplace justice. This article describes three campaigns led by the center. They reflect the exclusion of immigrant workers from coverage in policy areas related to heath care, compensation for workplace injury, and benefits for collective lay-offs in the textile sector. The paper concludes with some of the lessons learned in these campaigns.
\end{abstract}

Key words: immigrant, labor, campaigns, organizing, social policy.

\section{Introduction}

International migration has had a huge impact on the structure of labor markets throughout the world. The movement of people from poorer nations to richer ones in the search of greater economic opportunity has created a huge pool of workers, some with and others without formal immigration or legal status, who are willing and able to work under almost any conditions for both their own and family survival and in order to send money back home to their extended families. The mobility of labor can be understood as "labor reserve for global capital" (Sassen, 1988, p.36, as cited in Bauder, 2003). There is a large literature on this movement of people, but less on the way that they have organized themselves to contest the resulting working conditions. Internationally, migrant workers and their allies have created new forms of organizations and strategies to respond to their conditions through innovative means as well as the traditional union model, which has not been able to effectively organize these workers given the fragmented and unstable marketplace. 
Hanley, J. and Shragge, E. (2009). Organizing for Immigrant Worker Rights: Policy

Barriers and Community Campaigns. Journal of Community Practice 17(1-2).184-206

This article will discuss one of these organizations, the Immigrant Workers' Centre (IWC) in Montreal and the results of a research project undertaken to better understand the labor challenges facing its constituency. As members of the IWC Research Group, the authors helped conduct more than fifty semi-structured interviews between 2003 and 2007 with three distinct groups of immigrant workers: a group who had come for help to the IWC or were involved in the Centre; a group from Latin America who had been in Canada for at least 10 years; and a group with precarious immigration status such as refugee claimants, temporary workers, or undocumented workers. The interview guide explored issues such as migration trajectory, their work experience, and their resistance in the workplace where appropriate.

The IWC is an example of a community-based strategy linked with labor issues. We begin with a discussion of the particular context of immigrant labor in Canada. Against this background, the article will focus on areas of public policy that exclude immigrant workers or make it difficult for them to access specific so-called universal programs. Three campaigns in which the IWC has recently been involved (Summer 2008) will be discussed in order to examine these policy exclusions and an example of the IWC's grassroots response. The experiences of interview respondents will be used to illustrate the situations that led to these campaigns, revolving around: (1) the lack of benefits in case of workplace injury or illness for domestic workers; (2) a delay in free public health insurance for new arrivals; and (3) the difficulties in getting meaningful compensation in cases of large-scale lay-offs. Each of these issues illustrates government's inadequate response to mass migration and labor market restructuring. The article's conclusion will discuss lessons for building opposition of immigrant workers in the contemporary context.

Both of the co-authors of this article participated the founding of the IWC in 2000, and have remained active in it. Shragge is president of the Board of Directors and is active in the campaigns related to both health and safety legislation for domestics and justice for laid-off textile workers described below. Hanley is also a member of the board and is involved in the access to healthcare campaign. Both participate in bi-weekly team/staff meetings and supervise social work students who do their field placements at 
Hanley, J. and Shragge, E. (2009). Organizing for Immigrant Worker Rights: Policy

Barriers and Community Campaigns. Journal of Community Practice 17(1-2).184-206

the IWC. The information and perspectives of this article are derived from this ongoing involvement in the center over the past eight years.

\section{Immigrant Workers in Canada: An Overview}

In order to contextualize the emergence of the IWC and its practices, it is important to situate it within the transformations that have resulted from the immigration of the last 30 years. Historically, immigration has been used as a key component in the Canadian colonization project. Immigration policy contributes to maintaining a highly racialized construction of the Canadian nation with priority given to European immigrants up until the 1970s (Thobani, 2007). Non-Europeans were allowed in, often without full citizenship, to respond to specific demands for labor. Examples include the $19^{\text {th }}$ century importing of male Chinese labor to build railways while imposing extravagant landing fees (the "head tax") and prohibiting family reunification versus the easy citizenship offered to early $20^{\text {th }}$ century female British nannies and maids (Iacovetta, Draper and Ventresca, 1998).

In the past forty years the preponderance of European migrants has shifted, with a large increase in migrants from the south and a large influx of non-white immigrants. In 2007, for example, seven of the top ten source countries for permanent residents were "non-Western": China, India, Philippines, Pakistan, Iran, Korea, and Colombia. These top ten countries, with approximately 100,000 immigrants that year, represent nearly half the total permanent residents (CIC, 2008d). Forty years ago, the portrait was markedly different, with European, American, Australian and New Zealand immigrants representing more than a third of all immigrants (Employment and Immigration Canada, 1978, p.5-7). Many arrive with a high level of training and skills, usually including university education and advanced training (Picot, 2004). More than 60\% of adult immigrants arrive with post-secondary diplomas, with an even higher proportion for those coming from developing countries (CIC, 2008b). Despite these qualifications, immigrant workers find themselves disproportionately in low-wage jobs, with new immigrants facing chronically high levels of unemployment and poverty (Picot, 2004; Picot, Hou \& Coulombe 2007; Zietsma, 2007). 
Hanley, J. and Shragge, E. (2009). Organizing for Immigrant Worker Rights: Policy Barriers and Community Campaigns. Journal of Community Practice 17(1-2).184-206

In his groundbreaking review of immigration outcomes over the last 30 years, Picot (2004) argues that the traditional pattern of earnings for immigrant workers - that is, relatively lower income in the early years after their arrival and catching up with Canadians afterward - has not happened over that time period. For the group of immigrants that entered Canada in the 1970s, the earning gap has not narrowed as quickly as it had for previous groups of European immigrants. For those arriving in the 1980s and 1990s the gap has increased, and periods of economic growth and shrinking unemployment have not reduced this gap as would have been expected. Further, using the government's low-income cut-off (LICO) as a measure of poverty as a reference, immigrants have faced a deteriorating position. The proportion of recent immigrants with family incomes below the LICO rose from $24.6 \%$ in 1980 to $31.3 \%$ in 1990 and $35.8 \%$ in 2000. There has been a corresponding decrease for Canadians from $17.2 \%$ in 1980 to $14.3 \%$ in 2000 . Poverty rates for recent immigrants were 1.4 times higher than other Canadians' in 1980 and this grew to 2.5 times higher by 2000. This increase in lowincome rates is not restricted to new immigrants but includes all immigrant groups (Picot, 2004, p.11).

It is clear that despite high levels of education, immigrants tend to stay at the bottom of the labor market. This information challenges the myth that new immigrants are economically upwardly mobile. Lack of recognition of professional credentials has been identified as a major factor impeding the integration process (Aldridge \& Waddington, 2001; Austin \& Este, 2001; Krahn, Derwing, Mulder \& Wilkinson, 2000; Li, 2001). Ahmadi (2006) adds that during 2005 to 2006, there was a rising trend of job discrimination for both immigrant men and women. Given the changes from European immigration to that from the developing world, one can ask about the labor market and income stratification across racial lines. Meanwhile, in keeping with neo-liberal policy trends, new immigrants are increasingly viewed as commodities (Abu-Laban \& Gabriel, 2002; Arat-Koc, 1999). This "leads to an evaluation of people's potential contribution to and value to the country solely on the basis of their expected place in the labor market" (Abu-Laban \& Gabriel, 2002, p.65).

The period of arrival has a major impact on the material success of immigrant workers. Most of the users and members of the Immigrant Workers' Centre arrived in 
Hanley, J. and Shragge, E. (2009). Organizing for Immigrant Worker Rights: Policy Barriers and Community Campaigns. Journal of Community Practice 17(1-2).184-206

Canada in a period of labor market transition, a period of restructuring when the Fordist arrangement, with significant employment in unionized blue-collar jobs, was in decline and the new economy, characterized by services, new flexible working arrangements, and contingent work, was emerging. Such work includes "those forms of employment involving atypical employment contracts, limited social benefits and statutory entitlements, job insecurity, low job tenure, low wages and high risks of ill health" (Fudge \& Vosko, 2003, p. 183). It is the fastest growing pattern of employment, and youth, women, and immigrants tend to be absorbed into the labor market through these jobs (Fudge \& Vosko, 2003). This era of economic restructuring has been accompanied by cutbacks in social programs, such as language and job training, which have reduced the ability of new arrivals to gain skills that would help them in the Canadian job market (Abu-Laban \& Gabriel, 2002).

Another important trend in Canadian migration is the shift away from permanent residency towards what critics term "guestworker" programs. ${ }^{1}$ The current Conservative government has pushed ahead with a process started by the previous Liberal government to diminish the proportion of immigrants to Canada in favor of temporary foreign workers. This shift represents a major reduction in the state's obligation towards migrants and also is in close line with a "just-in-time", flexible management of the Canadian labor market; when we don't need them, we can just send them home. Migrants who arrive in Canada as permanent residents have a minimum level of security as a basis from which to refuse or resist substandard work conditions. Temporary workers, however, have their legal status in Canada tied to one specific employer and have very little leeway to object if they are not treated properly. They also have no guarantee of ever being able to remain in Canada on a permanent basis.

\footnotetext{
${ }^{1}$ Canada's immigration system has traditionally been conceived to respond to demand for labor through the admission of "Permanent Residents" (immigrants) based on a point system that takes into account such factors as age, education, language ability and employment prospects. They share all the same rights as Canadian citizens, apart from the right to vote. Three years after arrival, they are eligible for full citizenship. Temporary Foreign Workers (TFW), however, are restricted to work for the employer on their visa and are granted a 6 to 24-month work permit, after which time they have no guaranteed right to remain in Canada. For the first time in 2007, TFWers outnumbered the employment-oriented permanent residents admitted to Canada, with 115,000 TFWers (CIC, 2008a) versus only 94,000 permanent residents admitted for employment purposes as opposed to family or humanitarian motivations (CIC, 2008c).
} 
Hanley, J. and Shragge, E. (2009). Organizing for Immigrant Worker Rights: Policy Barriers and Community Campaigns. Journal of Community Practice 17(1-2).184-206

While this current trend toward guestworkers is striking, it is just a continuation of a differentiation among migrants that the state has imposed for quite some time and that shapes a lot of the work carried out at the IWC. We work with the concept of "precarious immigration status", the idea that when a person's immigration status does not confer the permanent right to remain in Canada and/or is dependent on a third party (usually a sponsoring employer or family member), that person is much more likely to experience exploitation and have a harder time defending themselves against it (Hanley \& Shragge, 2008). Precarious immigration status is a continuum that ranges from the undocumented (with virtually no rights) to sponsored family members (who share almost all the same rights as citizens but whose status as "sponsored" has been shown to engender serious feelings of dependency and vulnerability). In between, the Canadian immigration regime distinguishes between refugees (claimants, accepted or refused), temporary residents (tourists, students, humanitarian) and temporary workers (professional, live-in caregivers, seasonal agricultural workers, low-skill).

Of particular concern to our work at the IWC are the undocumented and those under temporary work visas, although refugees and students may also have the right to work in Canada. The Live-In Caregiver Program (LCP) and the Seasonal Agricultural Worker Program (SAWP) are the two temporary worker programs now being used as a template for an expansion into other supposedly "Low-Skill" fields of work through the "Low-Skill Pilot Project" under the Temporary Foreign Worker Program. Both of these programs tie the worker to one specific employer and restrict the stay in Canada (up to 36 months for the LCP and 10 months for the SAWP). Both programs require that the worker live on their employer's property. And while the LCP holds out the carrot of possible permanent residency if the (usually female and usually Filipino) caregiver completes 24 months of live-in work before the end of her 36-month program, farm workers are denied the possibility of permanent status. In both cases, access to basic labor protections is severely limited due to policy exclusions, employer interference, extreme dependence on the job, socio-economic barriers or some combination thereof. 


\section{Community Labor Organizing in Montreal: The Immigrant Workers' Centre}

The IWC is part of a wider movement in immigrant communities to integrate community and labor organizing. It is estimated that there are approximately 130 centers of this type across the United States (Fine, 2005), mainly in immigrant communities. These centers work with those closest to the bottom of the labor market. They are an important innovation in the field of community organizing, focusing on issues of labor outside of the workplace. Gordon describes these centers as seeking "...to build the collective power of their largely immigrant members and to raise wages and improve working conditions in the bottom-of-the-ladder jobs where they labor" (2005, p.280). Fine (2005), in her overview of these centers, states that they use a combination of the following approaches: service delivery including legal representation on issues such as wages and status; advocacy including research that exposes working conditions, and lobbying for policy or legislative change; and organizing including the development of leadership in immigrant communities in order to take action on their own behalf. As opposed to traditional labor organizing along craft or industry, these centers build on identification with race, ethnicity and place as key elements (Fine, 2005; Tait, 2005). In addition, they have tended to use direct action and lobbying as strategies rather than union and specific workplace organizing.

Fine (2005) argues that the success of these centers in improving working conditions for immigrant workers is derived from two sources. First, because of the limited power of immigrant workers, there are no other organizations that have succeeded in direct economic intervention on their behalf. Second, given the existing industrial structures and prevailing employment practices, only comprehensive changes in public policy can make a substantial difference. To understand the emergence of these centers, some elements related to their context will be examined, followed by an example of one center in Montreal, and conclude with lessons that emerge from practice.

The IWC was founded in 2000 by a small group composed of Filipino-Canadian union and former union organizers and their allies of activists and academics. The idea of 
Hanley, J. and Shragge, E. (2009). Organizing for Immigrant Worker Rights: Policy Barriers and Community Campaigns. Journal of Community Practice 17(1-2).184-206

the center grew out of the experience of two of the founders who had worked as union organizers. They observed that much of their recruitment and education to support a union drive had to take place outside of the workplace and there were few places where this could happen, particularly in a collective way. Thus the idea of the center was to provide a safe place outside of the workplace where workers could discuss their situation. Further, they had a critique of the unions themselves, arguing that once they got a majority to "sign cards" and join the union, the processes of education and solidarity built into the organizing process were lost as union "bureaucrats" came in to manage the collective agreement. In its first year, the IWC was able to secure a grant from the social justice fund of the Canadian Automobile Workers to intervene on labor issues in the community. The IWC then got to work providing ongoing education and critical analysis that goes beyond the specific role of unions, as well as finding ways to address worker issues outside of the traditional union structures.

The activities of the IWC cover individual rights counseling, popular education and political campaigns that reflect the general issues facing immigrant workers, such as dismissal, problems with employers or, sometimes, inadequate representation by their unions. Labor education is a priority, targeting organizations in the community and increasing workers' skills and analysis. Workshops on themes such as the history of the labor movement, the Labour Standards Act and collective organizing processes have been presented in many organizations that work with immigrants as well as at the IWC itself. The "Skills for Change" program teaches basic computer literacy, while incorporating workplace analysis and information on rights. The goal is to integrate specific computer skills while supporting individuals in becoming more active in defending labor rights in their workplaces. There is also an ongoing link between the struggles of immigrant workers with other social and economic struggles; building alliances is a priority. In addition, the IWC supports union organizing in workplaces where there is a high concentration of immigrant workers. The IWC, as an organization crosses traditional boundaries and has characteristics of a social movement organization through its participation in the wider movements for migrant justice and its structure with a board of directors and service provision and education programs is more in the tradition of nonprofits. (Hasenfeld, and Gidron, 2005). It can be understood as a social change 
Hanley, J. and Shragge, E. (2009). Organizing for Immigrant Worker Rights: Policy

Barriers and Community Campaigns. Journal of Community Practice 17(1-2).184-206

organization. Drawing from Chetkovich and Kunreuther (2006), these types of organizations support collective action for change and encourage individuals to take actions to improve their lives. The IWC has a clear vision that it is an organization engaged in collective action that emerges from the experiences lived by immigrant workers themselves.

Campaigns are viewed not only as a way to make specific gains for immigrant workers but also a way to educate the wider community about the issues that they face. For example, the first campaign, in 2000, was to defend a domestic worker, here under the Live-in Caregiver Program, against deportation. She had been unable to complete her 24 months of live-in work because she was fired by her employer when she became pregnant and was unable to find a new employer willing to have her live in with her infant son. In addition to winning the campaign, the issue of importing labor as 'indentured servants' was brought into the public sphere and many community organizations and unions became involved in this issue. Another example is how, along with many other groups in Quebec, the IWC became involved in a campaign to reform the Labor Standards Act in 2002. Because many immigrant workers do not work in unionized shops, the Labor Standards Act provides one of non-unionized workers' few recourses against their employers. The IWC brought to the campaign specific concerns including the exclusion of domestic workers from this Act and the difficulty in accessing information on workers' rights. In 2003, several victories were had, including the coverage of domestic workers by the reformed Labor Standards. However, despite the reforms won in this province-wide campaign, the Act still has many inadequacies in protecting workers in precarious and irregular jobs.

Another aspect of the IWC's work has been its contribution to the organizing of cultural events with political content. The first was an International Women's Day event organized in 2001. A coalition of immigrant women of diverse origins organized a cultural event, panels and a march to emphasize the concerns of immigrant women and international solidarity. This event has become an annual event and through its success has increased the profile and the issues faced by immigrant women within the wider women's movement in Quebec. The first MayWorks events, a community/union festival celebrating labor struggles through the arts, were launched for May Day of 2005. The 
Hanley, J. and Shragge, E. (2009). Organizing for Immigrant Worker Rights: Policy Barriers and Community Campaigns. Journal of Community Practice 17(1-2).184-206

festival was initiated by the IWC and found collaboration from trade unions and the wider activist community. The festival has been held annually since then and includes a community event in a local park as its core.

Overall, the IWC is a place of intersection between the traditions of the labor and community movements. Work-related issues have been the concern of the labor movement, acting on the assumption that the best way for workers to have a strong voice is through the union movement. However, the IWC, along with other organizations, sees that this is limited because of the difficulties in organizing workers mentioned above. New forms of labor organizing are required in the current context that both include support for and from the trade union movement. The IWC works at both levels with the goals of serving, organizing and educating those who are not unionized. At the same time, it supports worker efforts to unionize and to help them get adequate representation from their unions. The union-community relationship is developed through many activities of the Centre, including building alliances with younger union activists, supporting immigrants in organizing and in helping them negotiate conflicts with their trade unions.

The work of the IWC has formed new alliances and has become a meeting place for a many groups of social activists. The core of the organization is a group made up of immigrant union and labor organizers and allies who have been active on both labor and community issues for many years. In addition, the IWC is connected to what may be described as student and anti-globalization activists. There are several reasons for this. The center has been fortunate to have student placements from law, social work and related fields from several Montreal universities and colleges. Many of these students have been involved in student organizing and this has helped to connect students to the issues raised by the IWC. At the same time, the IWC's connection with these groups has pushed its own positions on broader social issues. The IWC is a place that brings together union-community and student activists, people of different ages, ethnic, cultural and class backgrounds to work together for social justice for immigrant workers. 
Hanley, J. and Shragge, E. (2009). Organizing for Immigrant Worker Rights: Policy

Barriers and Community Campaigns. Journal of Community Practice 17(1-2).184-206

\section{Exclusion of Migrant Workers from Social Protections: Government Policies and Grassroots Campaigns}

Canadian researchers have documented the policy and social barriers faced by immigrants in trying to access health and social services. They range from limited eligibility for programs, to systemic barriers within the health and social service network, to socio-economic and cultural factors of discrimination or disconnect (Oxman-Martinez et al, 2005; Baines \& Sharma, 2002; Zaman, 2004; Pierre, 2005). Issues of gender and immigration status have been shown to be of particular importance in understanding the barriers to health and social wellbeing (Preibisch, 2005; Guruge \& Khanlou, 2004). Further, research in Canada indicates that immigrants do not benefit from equitable access to social rights. For instance, when accessing the health care system, research has shown a significant proportion of immigrants to Canada experience delays, complications or denial of medically necessary treatment (Caulford \& Vali, 2006). This is particularly true of those with "precarious immigration status"- that is, those who are denied the permanent right to remain in Canada and/or whose status depends on a third party such as a spouse or employer (Hanley \& Shragge, 2009).

For migrants to Canada, barriers to health services are likely a composite of legal, institutional, socio-economic and cultural factors. Linguistic barriers often prevent or complicate communication and action (Gibson et al, 2005; Kopec et al, 2001; Zanchetta \& Poureslami, 2006). Also, migrants to Canada report cultural barriers, such as a lack of understanding of ethnic-specific norms and cultural incompatibility as a barrier in accessing institutional settings (Lai \& Chau, 2007; Stephenson, 1995). Such issues are likely exacerbated for those whose immigration status is precarious and for whom barriers to social rights are often systemic. Medicare policies, and the exclusion of temporary workers and recent immigrants from health services for the initial three months of their residency, act as a serious impediment to equitable health care (OxmanMartinez et al, 2005). Also, health costs and loss of wages due to work related injury may not be compensable or compensated due to provincial workers' compensation restrictions that lead to the de facto exclusion of many migrants (Lippel, 2006; Preibisch, 2007). Such policies are compounded by bureaucratic barriers, such as misfiling or 
Hanley, J. and Shragge, E. (2009). Organizing for Immigrant Worker Rights: Policy

Barriers and Community Campaigns. Journal of Community Practice 17(1-2).184-206

miscommunication, which increase the time for receiving social benefits (Gravel, Boucheron \& Kane, 2003). We turn our discussion to the organizing around these policy barriers, offering examples of campaigns undertaken by the IWC in alliance with others.

Here we will discuss examples of policy exclusion and the campaigns organized to oppose them: (1) the exclusion of domestic workers from health and safety policies that provide financial compensation for workplace injury or relate illness; (2) a threemonth exclusion from free public health insurance for new arrivals; and (3) the lack of meaningful compensation for workers being laid off from the textile sector. In the course of its day-to-day work, those seeking help have brought specific issues to the IWC. The experience of these individuals has led to campaigns; that is, going from case to cause. In each case, the policies and administrative structures of the provincial government are involved as all of the programs we will discuss below are legislated and administered through the provincial government. ${ }^{2}$

One of the key arguments that we will make is that these programs do not reflect an understanding of the recent wave of immigration to Quebec or the changes in the labor market such as increased flexibility, service sector development, irregular hours etc. Labor protection and other social programs assume full citizenship and the traditional structure of work. They do not take into account some of the situations facing immigrant workers, such as the type of jobs and the complex status questions described above. As we will see below, each campaign illustrates a wider issue facing immigrant workers and they are used to educate the general public and potential and actual allies about immigrant labor. We will describe the campaigns below and discuss lessons from them in the conclusion.

\section{CSST for Domestic Workers}

CSST is the French acronym for the Health and Safety Board or the Workers' Compensation Board of Quebec. ${ }^{3}$ CSST legislation addresses health and safety prevention and protective measures in the workplace as well as the compensation to

\footnotetext{
${ }^{2}$ In Canada, the provinces have the major responsibility for health, social services and labor. Even though there is federal transfer of funds, the provinces retain full control.

${ }^{3} \mathrm{CSST}=$ Commission de la sécurité et la santé au travail.
} 
Hanley, J. and Shragge, E. (2009). Organizing for Immigrant Worker Rights: Policy Barriers and Community Campaigns. Journal of Community Practice 17(1-2).184-206

which workers' are entitled should they be injured or become ill due to their employment. From its inception, domestic work (including housework as well as caring for children, elderly or disabled people, whether the worker lives in the home or not) has been excluded from the compensation aspect of the CSST due to the argument that a private home cannot be considered a "place of business". While all other labor legislation applies equally to domestic workers (although some only as of 2003), the employers of domestic workers are exempt from paying into the collective insurance regime of the CSST that would compensate their employees in cases of accident or illness.

Domestic workers have limited options when it comes to protecting themselves, despite the fact that domestic work is not without workplace hazards. It is important to recognize that domestic workers face many risks in their daily tasks, such as illness, infection, exposure to chemicals, awkward and repetitive tasks, heavy lifting, fatigue and stress. Apart from professional athletes, domestic workers are the only salaried workers who are not guaranteed CSST coverage by their employer. Domestic workers can register themselves or be registered through an association though in this situation, the cost of coverage is paid out of the worker's pocket, and not by their employer, as in the case of other employees. In case of accident or illness, they are told that they may pursue their employers through the civil courts but the unequal assets of the two parties make this a losing battle for the domestic worker.

Campaigns organized by the IWC often begin with an individual grievance. In this example, it was the case of a live-in domestic worker on the Live-In Caregiver Program, who became ill and unable to work due to unhealthy conditions in her employer's house, that was the beginning of the Centre's campaign around the CSST. Janet (not her real name), a live-in caregiver, came to Canada from the Philippines to work as a domestic. She had lived in a basement room and, because of certain chemicals in the room, developed a rash that was so severe that she could no longer work. She came to the IWC and asked for help. A representative of the IWC accompanied her to the CSST expecting that she would receive a hearing about her workplace-generated illness. The CSST response was that if she had been working in any other workplace than a private home, she would have received compensation from CSST. Before the IWC decided whether to launch a campaign, a social work student did research on these 
Hanley, J. and Shragge, E. (2009). Organizing for Immigrant Worker Rights: Policy Barriers and Community Campaigns. Journal of Community Practice 17(1-2).184-206

policies in other provinces in Canada. She found that three provinces in Canada (Ontario, British Columbia and Manitoba) offer compensation to domestic workers who suffer workplace injury or illness. This seemed like good leverage given that the government of Quebec has a tradition of viewing itself as a leader in social policy, such as its universal, $\$ 7 /$ day childcare system and network of community health agencies. After internal discussion, the IWC decided to launch a campaign to demand that domestic workers in Quebec be given full coverage in case of workplace accidents or illness.

A campaign committee was organized and led by three groups: the IWC, PINAY (a Filipina women's organization) and the Association des aides familiales du Québec (AAFQ, which represents and serves domestic workers). The demands for the campaign are: that current CSST legislation be extended to include the mandatory coverage of domestic workers, regardless of immigration status or validity of work permit; and that basic CSST information be available in languages other than French. In this context, the official language of Quebec is French; documents are available in English but many who work as domestic would be excluded by their inability to read these languages. The second demand was made to argue that the government has a responsibility to improve access to programs by informing people of their rights in a way that they can understand them and make appropriate claims. Representatives, volunteers and members from PINAY, the AAFQ and the IWC met as the organizing committee for the campaign, discussed and agreed with the demands and took the first steps to mobilize support. The IWC took the responsibility to circulate demands with an explanation to unions and women's organizations and community groups across Quebec. Over 80 organizations, including the large union federations, gave their support.

The campaign was launched on International Women's Day 2006. The strategy takes into account the fact that domestic work is not high on anyone's political agenda, including that of the groups and organizations supporting the campaign. The campaign therefore has a number of specific objectives: first, to keep the issue visible to both allies, and pressure the CSST bureaucracy and the Minister of Labor; second, to educate allies, potential allies and the general public on the issues faced by domestic workers, including that fact that domestic workers are workers; and third, to mobilize domestic workers to participate in the campaign. To date there has been some success in all three. For the first 
Hanley, J. and Shragge, E. (2009). Organizing for Immigrant Worker Rights: Policy

Barriers and Community Campaigns. Journal of Community Practice 17(1-2).184-206

two, visibility and pressure, it has been important to send material and updates to supporters of the campaign and remain in contact with labor representatives of the CSST board to inform them of the progress of the campaign and the response of both the minister and CSST officials. Education on the campaign, the LCP and domestic work in general has continued. One tactic has been the preparation of a popular theatre production by domestic workers. This was put on in a number of different venues such as during an educational event with women's organizations and in demonstrations in solidarity with refugee claimants. These have acted to sensitize both allies and the general public to their situation and the demands for CSST reform and the general situation of domestic workers. The media did a story on the popular theatre presentation. Domestic work is often invisible work and the goals of the IWC, PINAY and this campaign is to make it visible and point out that domestic work is work and domestic workers are workers, and entitles to the same rights as other workers.

The political target is both the CSST bureaucracy and the minister. A meeting with the minister was held in the summer of 2006 and he promised to involve representatives of the CSST campaign in an internal process within the CSST to examine the issue. This failed as the CSST bureaucrats did a superficial examination and did not appear to take the issue seriously. Subsequent pressure from the members of the campaign, union representatives on the CSST board, and a concern within the provincial government about the LCP resulted in a renewal of pressure on the CSST, and a new proposal for investigating how the government of Ontario has implemented this plan. The results of this are to be shared with the campaign committee in the Fall of 2008.

Despite all the activity in this campaign, the direct mobilization of domestic workers has been difficult. PINAY is the group that works directly with those women arriving in Canada on the LCP. It has used a variety of means to reach people as part of its overall organizing and specifically on the campaign, including a survey to discuss workplace health and safety questions. They have successfully built an organization base among Filipina domestic workers. Other mobilizing has been less successful. The general orientation of community organizations in Quebec is to represent what they see as the 'interests' of their clients/constituency and not to mobilize them. This has resulted in a process of broad-based collation building as a way to promote a particular issue rather 
Hanley, J. and Shragge, E. (2009). Organizing for Immigrant Worker Rights: Policy

Barriers and Community Campaigns. Journal of Community Practice 17(1-2).184-206

than direct organizing and mobilizing. Further, it is difficult to mobilize domestic workers as they are isolated, are vulnerable in their workplaces and only have Sundays off, not the best day for rallies or meetings targeting politicians and bureaucrats. PINAY has been successful in doing this because there is a basis of identity as migrant domestic workers arriving under a common program from the same country. The AAFQ, although in touch with many domestic workers, has not mobilized as they define themselves as a service and advocacy group and have received official recognition from the provincial government as 'the' representative of domestic workers. Thus the basic challenge is to find ways to reach domestic workers to engage them and help them organize themselves. On the whole, it has been hard going for the campaign with periods of some success such as getting a meeting with the minister of labor and periods of without progress but the commitment is there, many domestic workers are involved organized by PINAY, and the struggle continues.

\section{Health Care for All}

Another important campaign for the IWC has been the Health Care for All Campaign, demanding the abolishment of the 3-month waiting period (DDC or Délai de carence/waiting period) for Medicare imposed on migrants to Quebec (in the short term) and the extension of free healthcare to all (including the undocumented, in the long term). In the area of health care, Canada and the provinces have the legislated principles of universal, free and accessible care; however, in the case we discuss below, this is deliberately violated by the province of Quebec and several others. In theory, at least, the DDC was implemented to discourage people moving from one province to another seeking better services. For people moving within Canada, the issue is not so serious since they will still be covered by their province of origin's Medicare for the first three months. The problem is most serious among new immigrants and temporary workers who usually do not have alternate coverage and are therefore left uninsured.

Since 2001, all new residents in Quebec, especially immigrants and temporary workers, have had to wait three months from their declared arrival before being covered by public health insurance (the délai de carence or the DDC). More than 67,000 landed immigrants and temporary workers a year face this exclusion in Quebec. Under the DDC, 
Hanley, J. and Shragge, E. (2009). Organizing for Immigrant Worker Rights: Policy Barriers and Community Campaigns. Journal of Community Practice 17(1-2).184-206

new immigrants and temporary workers get stuck in the bottom tier of health care. The $D D C$ is part of a larger trend toward the privatization of Quebec and Canada's health care systems. The costs of this policy are being borne by new immigrants, to the profit of private insurance companies.

In the analysis of the IWC, the DDC ignores provincial, federal, and international human rights by preventing immigrants and temporary workers their right to physical and mental health. In theory, those rights should be exercised without discrimination of any kind. In reality, $84 \%$ of people that are not receiving Medicare for 3 months are new immigrants! For live-in caregivers and other temporary workers, they may even go through more than one 3-month delay, facing major obstacles to protecting their health.

When the DDC was implemented, the IWC started to see cases of people avoiding seeking health care when they needed it or, nearly as bad, people being saddled with debt into the tens of thousands of dollars. The first case that really illustrated this problem for the IWC was a man saddled with $\$ 37,000$ of debt when he fell on the ice outside his apartment building and broke his femur. He was absolutely unable to pay down this debt while supporting his family and he was terrified that this debt to the government would have a negative impact on his eventual goal of becoming a citizen. Another early case was a woman who came to work as a nanny in Canada on a temporary work permit under the Live-In Caregiver immigration program. Six weeks into her new job, she became very ill. Soon afterwards, she was diagnosed with cancer and was no longer able to work. Although she had been told that she would be covered by provincial health insurance, she discovered that there was a 3-month waiting period before she would become fully insured. Unfortunately, she had become ill before the three months were up and was facing hospital bills in the tens of thousands of dollars. Although she recovered from her cancer, the debt she accumulated has become a significant barrier to her dream of sponsoring her family to join her here in Canada.

Cases involving children have been particularly salient with the public and the media. Two recent cases involved very serious conditions. For example, within weeks of finishing their 3-month waiting period, a young girl suffered from repeated convulsions. Terrified, her family took her to the hospital where the doctor ordered a battery of tests. Her mother describes the horrible ordeal of having to discuss with the doctor which tests 
Hanley, J. and Shragge, E. (2009). Organizing for Immigrant Worker Rights: Policy

Barriers and Community Campaigns. Journal of Community Practice 17(1-2).184-206

could wait or not so that Medicare would cover them once their 3 months were finished. Nevertheless, the family incurred a huge debt for their child's treatment. In another case, a young boy fell from the play structure at the park after only a few days in Canada. He was rushed to the hospital and treated for a ruptured liver. The enormous bill was impossible for the family to pay since they had just spent all their savings to travel and settle in Canada.

Convinced that this was discriminatory and bad for Quebec society overall, the IWC teamed up with a number of other organizations to work on a campaign to abolish the DDC. Project Genesis, a neighborhood social rights organization, and PINAY, the Filipina Women's Association of Quebec (representing many Live-In Caregiver) are the two other groups in the coordinating committee. With support from more than 20 other organizations, including the biggest immigrant-serving coalitions of Quebec. The strategy has been to target the Health Minister and the provincial health insurance board in order to pressure them to remove the regulation from the books. Tactics have ranged from press conferences, to camping out in front of the Health minister's office to public education on the issue, to supporting individual families facing DDC debt.

In the case of the DDC campaign, it was Project Genesis (an ally of the IWC located just up the street) that took the first steps in initiating a campaign. They operate a drop-in storefront rights information clinic and had seen numerous cases of immigrant families saddled with massive debt due to unforeseeable medical problems (childhood appendicitis, car accidents, slipping on ice) shortly after their arrival in Canada. Given Canada's supposedly universal Medicare system, this situation seemed to go against the spirit of the law and Project Genesis organized a press conference with major immigration coalitions to call on the Quebec government to reverse its exclusion of new arrivals. When IWC organizers and activists saw this, it echoed a problem that we had been seeing among temporary foreign workers, especially LCP workers and in our collaborations with PINAY. We contacted Project Genesis in the summer of 2006 and, along with PINAY, the Health Care for All organizing committee was born. Since that time, dozens of Quebec organizations have signed on to our campaign and participate in specific events and actions. 
Hanley, J. and Shragge, E. (2009). Organizing for Immigrant Worker Rights: Policy

Barriers and Community Campaigns. Journal of Community Practice 17(1-2).184-206

Similar to the CSST campaign, the DDC campaign has had limited direct mobilization of those most affected by the issue. New arrivals to Quebec who don't encounter health problems (and most don't, having been pre-screened for health problems before being selected as immigrants or workers) don't often notice the lack of health coverage. And for those who do encounter problems, their relatively short time in Canada does not help them feel comfortable contesting publicly. Nevertheless, the campaign has documented a disturbing number of cases and research is beginning to show the negative effects of avoiding the use of health care services by those under the DDC. There is a core of about 10 families that is willing to speak publicly about the debt and stress they incurred as a result of the DDC and they participate in demonstrations, lobbying and media interventions.

There has been some movement on the issue. Several of the families who have gone public with their situation have had the debt collectors mysteriously back off and have been approached by opposition parties willing to support the campaign demands. Not so surprisingly, political insiders are encouraging the campaign to lessen its demands to ask only that children be covered immediately upon arrival. To date, campaign members have refused, finding this to be more of the same logic seen elsewhere in our social system (i.e. children deserve our sympathy, their parents are just trying to screw the system). Interestingly, it seems to be the connection to the LCP that is really moving the issue forward at the level of the Health Insurance Board. ${ }^{4}$ Years of organizing around the trampled rights of LCP workers have moved the current Quebec Minister of Immigration to put pressure on the CSST and the Health Insurance Board to reexamine their treatment of LCP workers and the DDC falls under this category. The Quebec Human Rights Commission is also investigating the DDC and CSST exclusion to determine whether these rules contravene Quebec's Charter of Human Rights. Activists are hopeful for change in the coming year.

\section{Justice for L'Amour Workers}

With globalization and the shifting of jobs to developing countries, the textile

\footnotetext{
${ }^{4}$ Health Insurance Board $=$ RAMQ $=$ Régie de l'assurance médicale du Québec
} 
Hanley, J. and Shragge, E. (2009). Organizing for Immigrant Worker Rights: Policy Barriers and Community Campaigns. Journal of Community Practice 17(1-2).184-206

sector in Montreal has been in serious decline. Once a prosperous and key sector of employment for immigrants back in the early $20^{\text {th }}$ century, the sector has recently lost many of its jobs to 'off-shore' production in poorer countries. Since its beginning, the IWC has dealt with cases of workers in this sector. Often, these cases have concerned unjust dismissal and lack of representation either because there were no unions or the unions were weak and did not adequately represent their members. Since 2007, there was an increase in the number of workers reporting job loss to the IWC. One company in particular came to the attention of organizers: L'Amour, a knitting factory that manufactured socks. There had already been cases brought through the IWC against L'Amour for its working conditions, such as the front door being kept locked and chained during the night shift. Under these conditions, workers were always in danger of being trapped because escape routes were limited in the case of an industrial fire. Often those doing piecework were not paid when machines broke down and they could not produce quotas. Workers were often forced to have meals at their stations while they continued to work, which meant that they virtually had no breaks. All of this was made worse by a union set up in 2004 and believed by many workers to be a "pro-management" union, preventing workers from organizing themselves and pressuring for changes in working conditions. This time, however, it became clear that company was shutting down production in Montreal with no compensation to the workers. A group of 25 workers, who have on average been working for this company for more than 10 years and some more than 20, was organized and began meeting. Another 50 at the beginning of August 2008 joined this group. The question is how does one respond to lay-offs?

Interviews with the workers reveal the depth of their anger and frustration with L'Amour $^{5}$. One former employee recounted how he had worked for forty hours a week for thirteen years, but was then laid off by L'Amour with no compensation beyond what he had earned. In our conversation, he emphasized how skilled he was, consistently pressing as many as 11,000 socks a day: "I was one of the special guys on the tube machine. Nobody like me." Another worker, who had worked as a knitter's helper for five years and then as a knitter for ten years until he was laid off by L'Amour, also

\footnotetext{
${ }^{5}$ These interviews were carried out by Yumna Siddiqi and were part of Siddiqi and Shragge (2008).
} 
Hanley, J. and Shragge, E. (2009). Organizing for Immigrant Worker Rights: Policy

Barriers and Community Campaigns. Journal of Community Practice 17(1-2).184-206

emphasized his skill and dedication to his work, and his sense of outrage that he had been so little valued: "I gave thirteen years of my life to them, and what I got, I got nothing."

Both workers also pointed to problems with their working conditions. They noted that workers on the night shift were locked in, often having to wait half an hour after their shift for the security guard to unlock the main door and let them out. The knitter said that workers had to work continuously for eight-hour shifts: "During that time we had no break, the machine running. We have no choice to go to eating place, to cafeteria, get fresh air." He was especially vexed by the fact that the L'Amour management played favorites among workers:

If they like employees, they say, 'OK, OK, OK! We want to keep that person.' Let's say I have no back up. Some person backs up the person. I hadn't back up. If I had back up, I would still be working at L'Amour. That's the policy at L'Amour. Let's say you are manager, you are so close to me, you save me, you say, 'Don't touch this person, I recommend this person.' But we are all good. We are all able to work. We are all skilled... so why do I need that person to back me up? I know how to work. I know how to work 25 machines. I was working a long time. Ten years, I was knitter. Five years, I was a knitter's helper. Why do I need someone to help me?

In discussion with the committee of workers from L'Amour, it became clear that returning to their old jobs was impossible and there were workers from other factories in the sector, who reported similar lay-offs. As well, L'Amour has become a very profitable company for its owners, boasting that it is a leading company in the apparel industry and has operations in places like China, Pakistan, Bangladesh and India with over 2500 workers worldwide. A long-time partner of the retail giant Wal-Mart, it recently broke into the US manufacturing market in July 2007 by taking over Terramar Sports, a company based in Tarrytown, New York, USA.

Through discussion, the workers decided on one significant demand, fair compensation for the years of loyalty they've shown this company. The situation is 
Hanley, J. and Shragge, E. (2009). Organizing for Immigrant Worker Rights: Policy

Barriers and Community Campaigns. Journal of Community Practice 17(1-2).184-206

complex. If the company had shut down entirely or laid off large numbers, the workers would be eligible for 'collective layoff benefits'. The company has chosen to layoff workers in small numbers but systematically, avoiding collective lay-offs and the related benefits. The strategy chosen is to pressure both the Labor Relations Tribunal for inadequate labor representation and the Labor Standards Board. The call is for these bodies to intervene and treat lay-offs as collective so that the workers will be eligible for much higher benefits. At the same time, a wider committee of workers from L'Amour and a couple of other factories facing similar conditions along with allies are working toward the development of a policy covering the workers in the declining textile sector. This campaign is one that involved workers, who are either not unionized or are represented by weak or pro-boss unions. In contrast, another company closed in Montreal with a strong union and the workers received a decent compensation package.

The situation of L'Amour workers is typical of that of other workers who come to he IWC, who have experienced the failure of government institutions that regulate the labor market to protect them. These state policies were established in a period in which most jobs were stable and regular. Those jobs currently in textiles are increasingly irregular, with a drive to reduce labor costs. This type of labor is difficult to regulate through existing policies and programs. Without the collective action of the L'Amour workers, there would have been no recourse and the individuals would have received little compensation with their lay-offs. News of this campaign has even traveled through word of mouth and ethnic media so that workers from other factories and even other cities have begun contacting the IWC with similar situations. Although it is difficult, the way forward is through political campaigns that not only challenge employers but also state bodies that are supposed to protect workers' rights.

\section{Concluding Comments}

The immigration tendencies in Canada over the past 30 years have been well documented. This wave of immigration is mainly non-white, from the South. Immigrant workers tend to be concentrated in sectors of the economy that are at the bottom despite 
Hanley, J. and Shragge, E. (2009). Organizing for Immigrant Worker Rights: Policy Barriers and Community Campaigns. Journal of Community Practice 17(1-2).184-206

their relatively high levels of education, and they remain there over long periods. The impacts of globalization and neo-liberalism are seen in massive human displacement, restructured labor processes and cutbacks in public services. These include a rising demand for cheap labor, particularly in the service sector such as its privatization, and in just-in-time production. Immigrant workers face precarious, low-paid, non-unionized jobs and exclusion from many health, safety and workplace policies. Beyond this are migrant workers without official status, who are forced to work below the minimal standards that theoretically protect other workers.

The campaigns being undertaken by the IWC reflect both the situations of immigrant workers and some of the emerging forms of organizing. Both the CSST and the DDC show how new immigrants are disproportionately excluded from public policies-health and safety. The L'Amour campaign demonstrates the precarious nature of the production in Canada and the arbitrary, unregulated working conditions. There are important lessons that the IWC has learned from these campaigns. First, it is difficult to organize immigrant workers around their workplaces, particularly those with precarious immigration status. There are many reasons for this, but it is important to be present and consistent and support people who come forward to challenge their employers. Working with individuals can be a precursor to building broader collective work. It is important to emphasize the mobilization of the workers themselves and to help support their leadership on the issues they face. Second, coalition building is necessary but not always easy. It takes a lot of time and work to educate allies about the conditions faced by immigrant workers and that they bring their own organizing and political traditions that do not always fit well with a more bureaucratic style in Quebec. As these issues are put in the public sphere immigrant workers can begin to take their place as political and social actors in the struggle for social and economic justice. Third, campaigns have to be addressed at both the employers and the state, in order to work toward justice for immigrant workers. It is difficult to win demands from employers who function within a liberalized market without changes in government policies and programs that would benefit workers in precarious jobs in unstable sectors of the economy.

Organizing labor in the community is a new form that gives voice and some power to groups of immigrant workers, who are the most marginalized group in the labor 
Hanley, J. and Shragge, E. (2009). Organizing for Immigrant Worker Rights: Policy Barriers and Community Campaigns. Journal of Community Practice 17(1-2).184-206

market. The related organizing processes and advocacy cross traditional boundaries of community and work. With some exceptions, labor has been the domain of the union movement. However with the changes described above worker centers have been founded to counter the difficulties faced by unions in the restructured labor market. However, it is not only linking community and labor that is an important crossover. Organizations like the IWC have been able to bring together younger activists, who began their engagement with the anti-globalization movement with older activists, and immigrant workers. This is a way that those involved in broader social and political questions can bring their energy and analysis into local activities. On the other side, these exchanges have brought the IWC closer to wider 'movement' activities such as Solidarity Across Borders. This exchange broadens both and brings the global and local together in a concrete way and creates an exchange between activists from different generations and different countries and traditions. Learning is a significant consequence for all involved, and the resulting alliances have grown out of these exchanges. One result is that the IWC, as with the revival of new forms of labor organizing in the United States takes on elements of a wider social movement and is not limited to local work (Clawson, 2003). The IWC through its many activities has become a place for building alliances and bring social actors, who are promoting social and economic justice, together.

There has often been a distinction drawn between direct service and organizing. Many community organizations are pushed to provide direct service by their funders and, as a result, their organizing activities become secondary. The IWC and similar community centers see individual service as a key way to attract people to their organizations. For an individual to step forward to challenge their boss on an issue of working conditions is an act of courage and is inherently political. And because individual problems are based in a workplace and in a policy context, they are often shared by others and form the basis for collective action. So, for organizations like the IWC, the issues brought in by community members contribute to building collective action and campaigns (Delgado, 1996; Gordon, 2005).

For community/labor organizing in general, the concept of working with individuals as a beginning point to initiate collective action is an important one to grasp and one that allows for more creative targets for change. It is often impossible to organize 
Hanley, J. and Shragge, E. (2009). Organizing for Immigrant Worker Rights: Policy

Barriers and Community Campaigns. Journal of Community Practice 17(1-2).184-206

directly in the workplace because of the precarious nature of many of the jobs of immigrant workers. Therefore, the target of their campaigns has been the state, demanding improvements in conditions for everyone at the bottom end of the labor market. Policy-oriented campaigns such as demanding improvements in labor standards or extending coverage of health and safety demand state intervention are the result. In the current climate, in which immigrant labor is used as a cheap pool that can be brought into workplaces or excluded as needed, new strategies that challenge exploitation are needed. The traditional union model has not been able to respond and organize most of the workers in these conditions. The emergence of worker centers with an immigrant membership is a start on the road to building a class movement for workplace justice alongside the union movement.

\section{References}

Abu-Laban, Y. \& Gabriel, C. (2002). Selling Diversity: immigration, multiculturalism, employment equity and globalization. Peterborough, Ont.: Broadview Press.

Ahmadi, E. (2006, June). Current employment conditions and learning practices of Canadian immigrant workers. Paper presented at the annual conference of the Work and Lifelong Learning Research Network (WALL), Ontario Institute for Studies in Education, University of Toronto.

Aldridge, F. \& Waddington, S. (2001). Asylum seekers' skills and qualifications audit pilot project. Leicester, UK: National Institute for Adult and Continuing Education.

Arat-Koc, S. (1999). Neo-liberalism, State Restructuring and Immigration: Changes in Canadian Policies in the 1990s. Journal of Canadian Studies, 34(2), 31-56.

Austin, C. \& Este, D. (2001). The working experiences of underemployed immigrant and refugee men. Canadian Social Work Review/Revue canadienne de service social, 18(2), 213-229.

Baines, D. \& Sharma, N. (2002). Migrant Workers as Non-Citizens: The Case against Citizenship as a Social Policy Concept. Studies in Pol Econ, 69, 75-28

Bauder, H. (2003). "Brain Abuse", or the Devaluation of Immigrant Labor in Canada. Antipode, 35(4), 699-717. 
Hanley, J. and Shragge, E. (2009). Organizing for Immigrant Worker Rights: Policy Barriers and Community Campaigns. Journal of Community Practice 17(1-2).184-206

Caulford P. \& Vali, Y. (2006). Providing health care to medically uninsured immigrants and refugees. CMAJ,194, 1253-1254.

Chetkovich, C. \& Kunreuther, F. (2006). From the ground up: grassroots associations making social change. Ithica: Cornell University Press.

Citizenship and Immigration Canada (CIC) (2008a) Facts and Figures 2007: Immigration Overview: Initial entry of foreign workers by top source countries. Ottawa: CIC.

Citizenship and Immigration Canada (CIC) (2008b) Facts and Figures 2007: Immigration Overview: Permanent Residents 15 years of age or older by source area and level of education. Ottawa: CIC.

Citizenship and Immigration Canada (CIC) (2008c) Facts and Figures 2007: Immigration Overview: Permanent Residents by category (Principal Applicants). Ottawa: CIC.

Citizenship and Immigration Canada (CIC) (2008d) Facts and Figures 2007: Immigration Overview: Permanent Residents by top source countries. Ottawa: CIC.

Clawson, D. (2003) The Next Upsurge: Labor and New Social Movements, Ithaca: ILR Press, Cornell university Press

Employment and Immigration Canada (1978). Immigration Statistics 1977. Ottawa: CIC.

Fine, J. (2005, March). Community Unions and the Revival of the American Labor Movement, Politics and Society, 33,(11), 54-199.

Gibson, N., Cave, A., Doering, D., Ortiz, L. \& Harms, P. (2005). Socio-cultural factors influencing prevention and treatment of tuberculosis in immigrant and aboriginal communities in Canada. Social Science \& Medicine,61, 931-942.

Gordon, J. (2005). Suburban Sweatshops: The Fight for Immigrant Rights, Cambridge Mass: Belknap Press of the Harvard University Press.

Gravel, S., Boucheron L \& Kane M, (2003). Workplace health and safety for immigrant workers in Montreal: Results of an exploratory study. Perspectives interdisciplinaires sur le travail et la santé,5.

Guruge, S. \& Khanlou, N. (2004). Intersectionalities of influence: Researching the health of immigrant and refugee women. Canadian Journal of Nursing Research,36,32-47.

Hanley, J. \& Shragge, E. (2009). Economic security for women with precarious immigration status: Enforcing labour rights for all; in Pulkingham J, Cohen GM (eds). 
Hanley, J. and Shragge, E. (2009). Organizing for Immigrant Worker Rights: Policy Barriers and Community Campaigns. Journal of Community Practice 17(1-2).184-206

Imagining public policy to meet women's economic security needs, Toronto: University of Toronto Press.

Hasenfeld,Y. \& Gidron,B. (2005). Understanding multi-purpose hybrid voluntary organizations: The contributions of theories on civil society, social movements and nonprofit organizations. Journal of Civil Society, 1, 97-112.

Iacovetta, F. with Draper, P. \& Ventresca, R., eds. (1998). A nation of immigrants: women, workers, and communities in Canadian history, 1840s - 1960s. Toronto: University of Toronto Press.

Kopec, J.A., Williams, J.I., To, T. \& Austin, P.C. (2001). Cross-cultural comparisons of health status in Canada using the health utilities index. Ethnicity \& health, 6, 41-50.

Krahn, H., Derwing, T., Mulder, M. \& Wilkinson, L. (2000). Educated and underemployed: Refugee integration into the Canadian labor market. International Journal of Migration and Integration, 1(1), 59-84.

Lai, D.W.L \& Chau, S.B.Y,(2007). Predictors of health service barriers for older Chinese immigrants in Canada. Health \& social work,3, 57-66.

Lippel, K. (2006). Precarious employment and occupational health and safety regulation in Quebec; in Vosko L (ed). Precarious employment: Understanding labour market insecurity in Canada. Montreal-Kingston: McGill Queen's University Press, pp 241-255.

Oxman-Martinez, J., Hanley J., Lach, L., Khanlou, N., Weerasinghe, S. \& Agnew V.(2005). Intersection of Canadian policy parameters affecting women with precarious immigration status: A baseline for understanding barriers to health. Journal of Immigrant Health, 7, 247-258.

Picot, G. (2004). Deteriorating economic welfare of immigrants and possible causes. Ottawa, ON: Statistics Canada. (Catalogue No. 11F0019MIE, No.222)

Picot, G., Hou, F. \& Coulombe, S. (January 2007). Chronic Low Income and LowIncome Dynamics Among Recent Immigrants. Statistics Canada, Catalogue No. 11F0019MIE, No.294.

Pierre, M.(2005). Factors of exclusion blocking the socioeconomic integration of certain groups of immigrant women in quebec. The current state. Nouvelles Pratiques Sociales, 17,75-94.

Preibisch, K.L. (2007). Patterns of social exclusion and inclusion of migrant workers in rural Canada. Ottawa, Ontario, The North-South Institute.

Preibisch, K.L. (2004). Migrant agricultural workers and processes of social inclusion in rural Canada. Cdn J of L.American \& Caribbean Stds, 29, 57/8, 203-239 
Hanley, J. and Shragge, E. (2009). Organizing for Immigrant Worker Rights: Policy Barriers and Community Campaigns. Journal of Community Practice 17(1-2).184-206

Shields, J. (2003). No safe haven: Markets, welfare, and migrants (CERIS Working Paper No. 22). Toronto: CERIS.

Siddiqi,Y. \& Shragge, E. (2008, September-October). The Empire's new clothes: where does boutique capitalism leave Montreal's garment workers? IBON Education for Development, 7(5), 20-24.

Stephenson, P.H.(1995). Vietnamese refugees in Victoria B.C.: An overview of immigrant and refugee health care in a medium-sized Canadian urban centre. Social Science \& Medicine, 40

Tait, V. (2005). Poor Workers' Unions :Rebuilding Labor from Below, Cambridge, Mass: South End Press.

Thobani, S. (2007). Exalted Subjects: Studies in the Making of Race and Nation in Canada. Toronto: University of Toronto Press.

Zanchetta, M.S. \& Poureslami, I.M.(2006). Health literacy within the reality of immigrants' culture and language. Canadian Journal of Public Health,97, S26-S30.

Zietsma, D. (2007, September). The Canadian immigrant labour market in 2006: First results from Canada's labour force survey. Ottawa, ON: Statistics Canada. (Catalogue No. 71-606-XIE) 